Marquette University

e-Publications@Marquette

$1-1-1998$

\title{
Relationships Between SERVQUAL Dimensions and Organizational Performance in the Case of a Business-to-Business Service
}

Subhash C. Mehta

National University of Singapore

Srinivas Durvasula

Marquette University, srinivas.durvasula@marquette.edu

Accepted version. Journal of Business \& Industrial Marketing, Vol. 13, No. 1 (1998): 40-53. DOI. This article is $\mathbb{C}$ Emerald Group Publishing and permission has been granted for this version to appear in e-Publications@Marquette. Emerald does not grant permission for this article to be further copied/ distributed or hosted elsewhere without the express permission from Emerald Group Publishing Limited. 


\title{
Relationships Between SERVQUAL Dimensions and Organizational Performance in the Case of a Business-to-Business Service
}

\author{
Subhash C. Mehta \\ Associate Professor of Marketing, \\ National University of Singapore \\ Singapore \\ Srinivas Durvasula \\ Senior Fellow of Marketing, National University of Singapore \\ Singapore \\ (Associate Professor of Marketing, on leave from \\ Marquette University \\ Milwaukee, USA)
}

\begin{abstract}
:
A growing recognition of the critical differences between industrial and consumer services requires additional research emphasis on marketing of services in business-to-business context. Presents an application of SERVQUAL as a measure of service quality in Ocean Freight Services. Based on a cross-section sample of 114 business organizations in Singapore, which regularly utilize ocean freight services for their export needs, the study asked shipping lines for their heaviest used export routes and provide their overall evaluation of services provided by their preferred suppliers. Respondents also evaluated various interfacing departments in the shipping line and SERVQUAL measures on various service quality dimensions. This study identifies the various strengths and weaknesses of the interfacing departments as well as in-service quality determinants. Further, the relationships between overall line performance, service quality, as well as specific customer service interfacing
\end{abstract}


NOT THE PUBLISHED VERSION; this is the author's final, peer-reviewed manuscript. The published version may be accessed by following the link in the citation at the bottom of the page.

departments are examined. The findings have important implications for shipping lines' marketing strategies. Though conducted in Singapore, the study is equally applicable to other Asian environments and NICs where many of the same lines are offering freight services to the exporting organizations.

Keywords: Asia-Pacific, Business-to-business marketing, Export, Organizational performance, Service quality, Shipping

\section{Introduction}

In recent years, service has been an area of highest growth as well as greatest research concern. However, most of the work in service has concentrated on consumer related service industries such as banking, travel, financial services, insurance, hospitality, and health care, etc. Little research has been conducted in the area of businessto-business services, though both academics and practitioners recognise that business-to-business relationships are characterised by closer and deeper interfaces than consumer relationships, and customer satisfaction is critical to the process of serving the customer and responding better than competition.

In the area of consumer services the issue of service quality has often been studied by the gaps model (Parasuraman et al., 1985, 1988, 1991, 1994; Zeithaml et al., 1990) which has served as a general framework for measuring the service quality as well as for enhancing it through gaps closure. Their research instrument is known as SERVQUAL. However, only one study could be found which addresses service-quality measurement in the business-to- business marketing of services by using SERVQUAL approach of gaps model (Farley et al., 1990). It is clear that more studies are needed in measuring customer evaluation of services in the organisational setting and this effort is a step in that direction.

As part of this study, organisational customers in Singapore, who regularly use the services of a shipping line for exporting their products, were investigated on their expectations as well as perceptions of the service quality offered by their preferred shipping lines on their heaviest used routes, using SERVQUAL as the measurement approach. One important objective of this paper then is to examine the relationships between SERVQUAL dimensions and service recipients' overall evaluation of the shipping lines' service. Next, this study also obtained service recipients' evaluation of the level

Journal of Business and Industrial Marketing, Vol 13, No. 1 (1998): pg. 40-53. DOI. This article is (C) Emerald and permission has been granted for this version to appear in e-Publications@Marquette. Emerald does not grant permission for this article to be further copied/distributed or hosted elsewhere without the express permission from Emerald. 
of service provided by shipping lines' interfacing departments (e.g. bookings) that come in contact with customers. The second major objective of this study is to examine relationships of SERVQUAL dimensions and overall evaluation of service with service ratings of shipping lines' interfacing departments. While applying the SERVQUAL in the business-to-business context, and as a secondary objective, this study also examines the relative efficiency of gaps (i.e. the differences between expectation and perception scores that reflect gaps in service quality) versus perceptions only measures. Using the relative importance of SERVQUAL dimensions as the weights, we also assess whether weighted or unweighted measures of gaps and perceptions have a stronger relationship with overall evaluation of the service provider.

Shipping was selected as an area for the study of business-tobusiness service quality because of its growing role in world trade. It is also a service widely used by business organisations around the world. Moreover, Singapore was seen as an ideal location for this study. On the supply side, Singapore is the second largest container port in the world, next only to Hong Kong, but often capturing the top spot. On the demand side, it is a major trading and transshipment centre with annual international trade even exceeding the GNP. The findings of this study, however, should be of interest to customers of shipping lines as well as the lines themselves elsewhere. In fact these preferred shipping lines generally operate around the globe with operational offices in every major port of the world.

The rest of the paper is organised as follows. First, the SERVQUAL scale is briefly reviewed. Second, a brief review of literature under the title "Service encounter" is provided to identify the relationship between service recipients' ratings of individual interfacing departments and the overall perception of the service provider. The methodology for this study is provided next. Then major results of this study are provided, followed by a discussion of the study's findings.

\section{About the SERVQUAL scale}

Because of the explosive growth in the research on service quality, a number of models of service quality have emerged in the literature. Important among these are Grönroos' (1984), Schary's (1979), and Parasuraman et al.'s (1985) models, the last mentioned being the most widely used. A key aspect of this model is the

Journal of Business and Industrial Marketing, Vol 13, No. 1 (1998): pg. 40-53. DOI. This article is @ Emerald and permission has been granted for this version to appear in e-Publications@Marquette. Emerald does not grant permission for this article to be further copied/distributed or hosted elsewhere without the express permission from Emerald. 
customers' determination process for perceived service quality. According to the authors, expected service and perceived service are both directly influenced by the determinants of service quality which finally determine the overall level of service quality. With the help of depth interviews as well as focus group discussions with firms in four different service industries, ten different determinants were identified and these were access, communication, competence, courtesy, credibility, reliability, responsiveness, security, tangibles and customer knowledge. Subsequent research (Parasuraman et al., 1988) condensed these ten determinants into five, leading to the development of SERVQUAL, a 22-item scale designed to measure service quality. The five determinants in the scale are tangibles, reliability, responsiveness, assurance and empathy. The final two dimensions, namely assurance and empathy included in them seven of the original ten dimensions. The experience with the use of this research instrument led to some amendments later (Parasuraman et al., 1991,1994; Zeithaml et al., 1990).

SERVQUAL has also been widely examined for its validity and reliability (Bolton and Drew, 1991; Brown and Swartz, 1989; Carman, 1990; Cronin and Taylor, 1992, 1994). Even though some of these studies failed to support the five dimensional factor structure, Parasuraman et al. (1993) defended the use of those five dimensions based on conceptual and practical grounds. An important area of criticism of SERVQUAL has been the use of gap scores in the measurement of service quality (Cronin and Taylor, 1992, 1994). Cronin and Taylor (1992) compare these expectation- perception gaps versus perceptions only, which they call SERVPERF and conclude that measurement of service performance (perception) alone is adequate.

Some authors also raised issues regarding the relative importance of the five dimensions which Parasuraman et al. (1988) initially determined by inference. In their later refinements, they explicitly asked customers to allocate 100 points among the five broad dimensions. Cronin and Taylor (1992) tested an importance weighted SERVPERF and found a high correlation between weighted and unweighted measures. They concluded that unweighted SERVPERF is sufficient.

While using SERVQUAL in the business-to-business context, this study also examines the relative efficiency of gaps versus perceptions only measures and weighted versus unweighted measure of gaps and

Journal of Business and Industrial Marketing, Vol 13, No. 1 (1998): pg. 40-53. DOI. This article is @ Emerald and permission has been granted for this version to appear in e-Publications@Marquette. Emerald does not grant permission for this article to be further copied/distributed or hosted elsewhere without the express permission from Emerald. 
perceptions using relative importance ratings of dimensions. In this study, the five SERVQUAL dimensions proposed by Parasuraman et al. (1991) are used for assessing relationships among SERVQUAL determinants and ratings of interfacing customer service departments.

\section{Service encounter}

The interaction between service providers and the customer has been termed "service encounter" (Bitner et al., 1990), "moment of truth" (Albrecht, 1988; Cina, 1990) and "boundary spanning" (Leiler and Delbecq, 1978). According to Bitner (1990), customers' overall satisfaction with service depends primarily on the management and monitoring of those service encounters which take place between the customer and the boundary spanners of an organisation. Booms and Nyquist (198I) contend that differentiation between service firms depends considerably on the interaction between the customer, whom they term as experiencer, and the contact persons. According to Bowen and Schneider (1988), the customer's perception of the quality of service received is affected by the behaviour of the person delivering the service. The service recipient even equates the service quality with the persons who provide it.

Recent studies distinguished customer satisfaction and service quality, suggesting that they are two separate yet related constructs (see Iacobucci et al., 1994; Patterson and Johnson, 1993).

Nevertheless, investigations in both customer satisfaction and service quality have found the service encounter to be critical to the perceived level of satisfaction in the various industries (Brown and Swartz, 1989; Crosby and Stephens, 1987; Day and Bodur, 1978; Quelch and Ash, 1981; Westbrook, 1981). The employees delivering the service are often called boundary spanners because they bridge the gap between the service provider and the customer (Leifer and Delbecq, 1978). The customer's perception of the service provider is very much based on these boundary spanners and the departments to which they belong, which are known as the interfacing departments (Weitzel et al., 1989).

Davidson (1984) suggests that the secret to running a successful service organisation is to turn the organisation chart "upside down," where service provider is located at the top of the organisation, indicating thereby the level of importance to be extended to the boundary spanners. Of course, both the contact persons as well as support personnel are critical to the service performance. Blume

Journal of Business and Industrial Marketing, Vol 13, No. 1 (1998): pg. 40-53. DOI. This article is @ Emerald and permission has been granted for this version to appear in e-Publications@Marquette. Emerald does not grant permission for this article to be further copied/distributed or hosted elsewhere without the express permission from Emerald. 
(1988) emphasises this position by stating that customer service is an organisation-wide effort, involving people who have face-to-face contact with customers as well as people who serve customers indirectly.

Based on the foregoing discussion, an important objective of this paper as stated in the "Introduction" section, is to examine the relationships among customers' ratings of shipping lines' interfacing departments, perceptions of service quality as measured by SERVQUAL, and the overall performance evaluation of the preferred lines. The findings of this study may help upgrade the services of the shipping lines and enhance their service quality to organisational customers who in turn, may be able to better serve their own international customers.

\section{Method}

\section{About the survey measures}

For the purpose of service delivery to the customers, shipping lines often divide their organisations into specialised departments, each department, directly or indirectly, having an interface with the customers. Most commonly found departments in the shipping lines are: sales and marketing; bookings; documentation; operations and claims. In addition, the customer also uses the telephone service and many a time personally visits the office of the shipping lines. The customer's perception of the line's service quality should be determined considerably by his experience with these contact or support persons in the service provider's organization. This study therefore included a measure of customer's evaluation of the service provided by these departments on a I (worst service) to 7 (excellent service) scale. Items included to measure performance of these departments or support services were generated from a search of the literature on carrier selection (Baker, 1980; Chattopadhyay, 1990; McGinnis, 1979; Raghunathan et al., 1988) as well as in-depth discussions with shippers and shipping lines.

Another part of the fully structured questionnaire included SERVQUAL statements covering both expectations as well as perceptions. Each of these two aspects had 22 statements adapted to the attributes of shipping lines, measured on 1 (not at all essential) to 7 (absolutely essential) scale for the expectations and 1 (strongly 
disagree) to 7 (strongly agree) for perceptions (or performance) evaluation (the instructions and the scale items for the SERVQUAL scale are consistent with those recommended by Parasuraman et al., 1991). Importance of the SERVQUAL dimensions was also measured through allocation of 100 points by the respondents among the five dimensions. Finally, the questionnaire included a measure of the overall evaluation of the shipping lines services on 1 (extremely poor) to 7 (excellent) scale. The questionnaire also included background information on the responding organisation, such as nature of business, ownership, size, and annual export freight costs.

\section{About the sample}

The sample consisted of 114 shipping managers from a crosssection of as many organisations in Singapore using ocean freight for their exporting requirements. This sample was randomly drawn from a listing of all regular shippers in Singapore available with a large shipping line, which maintained a comprehensive listing of both customers as well as prospects. The type of companies represented by the respondents include manufacturing, trading, or both.

These companies deal with consumer products as well as industrial products with an annual turnover ranging from less than $\$ 10$ million (for 49 of the companies) to more than $\$ 25$ million (for 26 per cent of the companies). While 50 per cent of the companies are locally owned, 31.6 per cent are joint ventures and 18.4 per cent are foreign owned. The annual freight expenses of these companies varied from $\$ 25,000$ (for about 26 per cent of the sample) to over $\$ 100,000$ (for about 35 per cent of the sample).

\section{Results}

\section{Evaluation of interfacing departments/activities}

Based on responses to multi-item scales, Table I provides mean ratings of different customer interfacing departments/activities and identifies strengths and weaknesses in their perceived performances. Reliability of items included to cover different aspects of an activity/department is generally very high, minimum Cronbach alpha being 0.91 . Since the mean ratings shown in Table I are ratings on the preferred lines, weaknesses are relatively less pronounced with means generally above 5 on a 7-point scale. The overall (or grand) mean evaluation rating across the seven interfacing departments is 5.45 .

Journal of Business and Industrial Marketing, Vol 13, No. 1 (1998): pg. 40-53. DOI. This article is (c Emerald and permission has been granted for this version to appear in e-Publications@Marquette. Emerald does not grant permission for this article to be further copied/distributed or hosted elsewhere without the express permission from Emerald. 
Given this, booking services (mean $=5.68)$, operations (mean $=$ 5.58 ), and documentation (mean $=5.55$ ) departments are rated as the top performing departments/activities in that order. Claims and experience of personal visits to shipping lines' offices are relatively poorly rated, with mean ratings at or below 5.3. Performance of sales/marketing representatives and telephone service of the lines also require upgrading.

Next, overall mean rating for the department/activity is used as a cut off to identify strong or weak points relating to that particular activity. For example, the mean rating of bookings department is 5.68. As the item "availability of space" has a mean of 6.09 (and above the department mean of 5.68), it is considered as a strong point. On the other hand, as the item "advice on delays" has a mean of 5.21 (and less than the department mean of 5.68), it is considered as a weak point for preferred shipping lines. Proceeding with this analysis, across the seven departments, advice on delays (booking services), ability to get assistance from port authorities (operations), assistance on closing time extension (operations), flexibility in releasing bills of lading (documentation), accommodating special needs (documentation), promptness in answering telephone (telephone service), regularity of visits (sales representatives), ability of sales representatives to obtain co- operation of others in the company (sales representatives) and sensitivity of employees to customers (personal visits) are indicated as major weak spots in the services of the preferred lines.

\section{[Table I}

\section{Evaluation of SERVQUAL dimensions}

Table II provides mean ratings of SERVQUAL factors and identifies strengths and weaknesses in specific aspects of these factor dimensions. It is clear that with the exception of the perceptions measure of tangibles, all other scales have acceptable internal consistency estimates with alpha values above 0.7 . Next, consistent with the procedure used for interfacing departments/activities, overall mean ratings for each SERVQUAL factor was used to identify strong and weak points relating to that particular factor. In terms of expectations, reliability $($ mean $=6.01)$ and responsiveness $($ mean $=$ 
6.03) were considered as the most critical determinants of service quality followed by assurance (mean $=5.94$ ) and empathy (mean = 5.76). Expectation on the tangibles dimension was the least, with a mean of 4.97. As regards perception (or performance), preferred shipping lines were rated tops on assurance and responsiveness (where means are above 5.5), followed by reliability and empathy. Again, perception score on the tangibles was the lowest at 5.04. The gap was, however, least on tangibles, where perception often exceeded expectation. The major gaps were in the dimensions of reliability and responsiveness, where shipping lines appear to be faltering. Regarding the importance of dimensions, as explicitly stated by the shipping managers, the order that emerged was: reliability; responsiveness; assurance; tangibles; and empathy in that descending order.

\section{Choice of appropriate model}

Before examining correlations between performance of interfacing departments/activities in the shipping lines and SERVQUAL dimensions, the choice of an appropriate model had to be made. Since it is debatable whether gap scores or performance scores should be used for analysis and also whether these should be weighted by the importance rating or not, a comparison of these four models was necessary. Hence, correlations were obtained between overall evaluation of the preferred lines and SERVQUAL dimensions based on gaps and performance, each weighted or unweighted. Results showed that unweighted perception (or performance) scores correlate best with overall evaluation, with all correlations being significant and ranging from 0.29 to 0.51 . All other correlations with overall evaluation, featuring unweighted gap scores, weighted perception scores and weighted gap scores are significantly smaller (see Table III). Hence, only perception scores are used to examine relationships with interfacing departments/ activities of the supplier organisation.

\section{[Table II]}

Journal of Business and Industrial Marketing, Vol 13, No. 1 (1998): pg. 40-53. DOI. This article is @ Emerald and permission has been granted for this version to appear in e-Publications@Marquette. Emerald does not grant permission for this article to be further copied/distributed or hosted elsewhere without the express permission from Emerald. 


\section{Relationships between SERVQUAL dimensions and interlacing departments}

Correlations between interfacing departments/activities performance and SERVQUAL dimensions were computed next. As shown in Table IV, results indicate that performance of all these activities is highly correlated with the customer perception of the line's overall evaluation. Except for claims, which is evaluated low (mean of 4.94) and has a poor correlation with overall evaluation of the preferred line (0.37), all other correlations are over 0.63 . However, all interfacing departments, including claims, have a sizeable correlation of at least 0.52 with overall (total) service quality measure, as computed from perception scores only on the five SERVQUAL dimensions. Of course, the highest correlations of service quality determinants are with experience of personal visits, operations, sales/marketing representatives, and booking services, which are the primary direct contact points for the customers. Except for tangibles, all other SERVQUAL dimensions are well correlated with overall line evaluation.

\section{[Table III]}

\section{[Table IV]}

As for each dimension, personal visits and perception about operations are critical to the feeling of assurance. Responsiveness and reliability depend primarily on personal visits experience, sales representatives and operations. Correlations of empathy and tangibles are generally not as strong. Empathy is felt more through personal visits and interaction with sales representatives. Tangibles dimension has only moderate correlations with interfacing departments. This was an area earlier identified as having the least gaps between expectations and performance.

\section{Discussion}

Service quality is a critical concern in business-to-business marketing of services because of its impact on the organisational 
customers' own service to their customers. Poor shipping services can have drastic consequences on the exports business of the organisations who may face loss of orders, increased claims, lower prices, delayed payments and generally lower supplier ratings. In today's highly competitive environment and global markets, services of shipping lines can provide an important competitive differential advantage to the exporters. Shipping lines provide their customer services through a number of specialised departments having either direct contact with customers or providing support services indirectly. Service delivery is a total system operationalised through the performance of subsystems such as marketing and sales, bookings, documentation, operations and claims. In addition, customers use telephone services to the lines for inquiries, information and follow up and at times visit the line's office personally to expedite matters, resolve problems or generally monitor their shipments. It is clear that any weak chain in these subsystems can cause concerns and lower service providers' service quality perceptions. The study clearly establishes a strong linkage between interfacing organisational performance and service quality perceptions.

While there are some differences in the strength of relationships between these subsystems performance and determinants of service quality, except for relationships with tangibles dimension, which are relatively weak, all other qualitative determinants of service quality such as assurance, responsiveness, reliability and empathy are fairly strongly correlated with interfacing organisational performance. The only subsystem which is somewhat poorly related is claims, which in any case arise largely because of service failure. In particular, operations, sales and marketing representatives, booking services and experience of personal visits to the line's office are relatively more important in generating a feeling of assurance, reliability and responsiveness etc. in the organisational customers. Generally, the results indicate that preferred shipping lines are providing a high level of service quality to their customers, though there is some feeling that physical facilities as well as other tangibles offered by these service providers may have room for improvement. It is quite likely, however, that not all shipping lines will receive the same high ratings as those of preferred shipping lines. Hence, the service quality ratings of preferred shipping lines found in this study may serve as a standard or benchmark that shipping lines in general would like to achieve.

Journal of Business and Industrial Marketing, Vol 13, No. 1 (1998): pg. 40-53. DOI. This article is (c Emerald and permission has been granted for this version to appear in e-Publications@Marquette. Emerald does not grant permission for this article to be further copied/distributed or hosted elsewhere without the express permission from Emerald. 
NOT THE PUBLISHED VERSION; this is the author's final, peer-reviewed manuscript. The published version may be accessed by following the link in the citation at the bottom of the page.

This study once again raises questions about the use of gap scores as suggested by SERVQUAL authors for measuring service quality. It clearly indicates that relative importance measures of service quality determinants as well as expectation measures are unnecessary and unweighted measures of perceptions alone are adequate in indicating service quality levels in business-to-business services.

While this study represents one of only a few studies that extended SERVQUAL scale to business-to-business services, it does not propose an alternative scale to measure service quality. Future studies in this area are very much needed to address this concern and to provide a simpler alternative to SERVQUAL.

\section{Managerial implications and recommendations}

A review of weak points identified in different aspects of the shipping services points towards the need for an account management concept which can integrate the total service and draw from the resources of the entire organisation in providing a high standard of service to the customers and meeting their diverse needs. Such a concept will reduce the need for customers' direct contact with multiple agencies in the shipping line's organisation. Account managers can also gradually move towards relationship marketing so that they are responsible for total customer service and target to achieve a major share of the customer's overall freight business for different routes and destinations. Such a move will also enhance service providers' ability to keep their customers for substantially extended periods and even for life.

The study also provides benchmark performance standards for the ocean freight industry. Shipping lines can examine the strengths and weaknesses of the top ranking shipping companies which enjoy high preference from the organisational customers involved in international export markets, in both organisational performance as well as customer perceptions of service quality. They can try to upgrade their service performance to bring it closer to the high performing lines.

For shipping lines interested in upgrading their services on an ongoing basis, the study provides directions for measuring service quality performance periodically. It provides methodological guidelines

Journal of Business and Industrial Marketing, Vol 13, No. 1 (1998): pg. 40-53. DOI. This article is @ Emerald and permission has been granted for this version to appear in e-Publications@Marquette. Emerald does not grant permission for this article to be further copied/distributed or hosted elsewhere without the express permission from Emerald. 
as well as suggestions on operationalisation of variables which can be used for monitoring performance. Through marketing research on customers and prospects, shipping lines can simply measure performance perceptions on seven subsystems indicated in this study to cover all interfacing activities. They can also use a simplified version of service quality measurement without including customer expectations or even relative importance of service quality determinants. A parsimonious approach appears adequate to monitor the service quality changes and explain customer performance perceptions.

An interesting finding of this service is the fact that performance perceptions do not depend on only a few aspects like operations or marketing representatives etc. Almost every interfacing activity and indirect support system has an impact on customer evaluation of the service, and shipping lines need to adopt an integrated approach. Almost every member of the organisation is critical to the provision of quality service and organisations have to create an internal culture which is responsive to customer needs, problems and expectations.

There is a great deal of interest these days among service organisations to obtain quality certification like ISO 9000. At least in Southeast Asia and Pacific Rim countries, where there is a great deal of heterogeneity in service performance of different organisations, such certification provides a competitive edge and gives customers a level of credibility and confidence in the service provider. A market feedback collected along the lines suggested in this study can be an important input in enabling service organisations to obtain such a certificate.

Finally, while this study is based on Singapore-based organisational customers' evaluations of shipping lines' service, the procedure outlined in this study can be easily applied to other Asian environments and newly industrialised countries where many of the same shipping lines offer freight services to exporting organisations. At the same time, this approach can also be used to evaluate service quality of other types of business-to-business services.

\section{References}

Albrecht, K. (1988), At America's Service, Dow Jones-Irwin, Homewood, IL.

Journal of Business and Industrial Marketing, Vol 13, No. 1 (1998): pg. 40-53. DOI. This article is (C) Emerald and permission has been granted for this version to appear in e-Publications@Marquette. Emerald does not grant permission for this article to be further copied/distributed or hosted elsewhere without the express permission from Emerald. 
NOT THE PUBLISHED VERSION; this is the author's final, peer-reviewed manuscript. The published version may be accessed by following the link in the citation at the bottom of the page.

Baker, G.H. (1980), "The carrier eliminations decision: implications for motor carrier marketing," Transportation Journal, Vol. 24, September, pp. 20-9.

Bitner, M.J. (1990), "Evaluating service encounters: the effects of physical surroundings and employee responses," Journal of Marketing, Vol. 54, April, pp. 69-82.

Bitner, M.J., Booms, B.H. and Tetreault, M.S. (1990), "The service encounter: diagnosing favorable and unfavorable incidents," Journal of Marketing, Vol. 54, January, pp. 71-84.

Blume, E.R. (1988), "Customer service: giving customers the competitive edge," Training and Development Journal, Vol. 42, September, pp. 2431.

Bolton, R. N. and Drew, J.H. (1991), "A longitudinal analysis of the impact of service changes on customer attitudes," Journal of Marketing, Vol. 55, January, pp. 1-9.

Booms, B.H. and Nyquist, J.L. (1981), "Analyzing the customer/firm communication component of the services marketing mix," in Donnelly, J. and George, W. (Eds), Marketing of Services, American Marketing Association, Chicago, IL, pp. 171-7.

Bowen, D.E. and Schneider, B. (1988), "Services marketing and management: implications for organizational behavior," in Staw, B.M. and Cummings, L.L. (Eds), Research in Organizational Behavior, Vol. 10, JAI Press, Greenwich, CT, pp. 43-80.

Brown. S.W. and Swartz, T. (1989), "A gap analysis of professional service quality," Journal of Marketing, Vol. 53, April, pp. 92-8.

Carman, J.M. (1990), "Consumer perceptions of service quality: an assessment of the SERVQUAL dimensions," Journal of Retailing, Vol. 66 No. 1, pp. 33-55.

Chattopadhyay, S.P. (1990), "Investigation of the effects of organisational and environmental variables and source loyalty on the motor carrier selection decision," Doctoral Thesis, Virginia Polytechnic.

Cina, C. (1990), "Five steps to service excellence," The Journal of Services Marketing, Vol. 4, Spring, Vol. 39-47.

Cronin, J.J. Jr and Taylor, S.A. (1992), "Measuring service quality: a reexamination and extension," Journal of Marketing, Vol. 56, July, pp. 55- 68.

Journal of Business and Industrial Marketing, Vol 13, No. 1 (1998): pg. 40-53. DOI. This article is (C Emerald and permission has been granted for this version to appear in e-Publications@Marquette. Emerald does not grant permission for this article to be further copied/distributed or hosted elsewhere without the express permission from Emerald. 
NOT THE PUBLISHED VERSION; this is the author's final, peer-reviewed manuscript. The published version may be accessed by following the link in the citation at the bottom of the page.

Cronin, J.J. Jr and Taylor, S.A. (1994), "SERVPERF vs SERVQUAL: reconciling performances based perception - minus - expectations measurement of service quality," Journal of Marketing, Vol. 58, January, pp. 125-31.

Crosby, L.A. and Stephens, N.J. (1987), "Effects of relationship marketing on satisfaction, retention and prices in the life insurance industry," Journal of Marketing Research, Vol. 24, November, pp. 404-11.

Davidson, D.S. (1984), "How to succeed in a service industry: turn the organizational chart upside down," in Lovelock, C.H. (Ed.), Service Marketing, Prentice-Hall, Englewood Cliffs, NJ, pp. 476-9.

Day, R.L. and Bodur, M. (1978), "Consumer response to dissatisfaction with services and intangibles," in Hunt, H.K. (Ed.), Advances in Consumer Research, Vol. 5, Association for Consumer Research, Ann Anbor, MI, pp. 263-272.

Farley, J.M., Daniels, C.P. and Pearl, D.H. (1990), "Service quality in a multinational environment," 1990 ASQC, Quality Congress Transactions, San Francisco, CA.

Grönroos, C. (1984), "A service quality model and its marketing implications," European Journal of Marketing, Vol. 18 No. 4, pp. 36-44.

Iacobucci, D., Grayson, K.A. and Ostrom, A.L. (1994), "The calculus of service quality and customer satisfaction: theoretical and empirical differentiation and integration," in Swartz, T.A., Bowen, D.A. and Brown, S.W. (Eds), Advances in Services and Marketing and Management, JAI Press, Vol. 3, pp. 1-67.

Leifer, R.P. and Delbecq, A. (1978), "Organization/environment interchange: a model of boundary spanning activity", Academy of Management Review, Vol. 3, January, pp. 40-50.

McGinnis, M.A. (1979), "Shippers attitude towards freight transportation choice: a factor analysis study," International Journal of Physical Distribution \& Materials Management, Vol. 10 No. 1, pp. 25-34.

Parasuraman, A., Berry, L.L. and Zeithaml, V. (1988), "SERVQUAL: a multiple- item scale for measuring consumer perceptions of service quality," Journal of Retailing, Vol. 14, Spring, pp. 12-39.

Parasuraman, A., Berry, L.L. and Zeithaml, V.A. (1991), "Refinement and reassessment of the SERVQUAL scale," Journal of Retailing, Vol. 67, Winter, pp. 420-50.

Journal of Business and Industrial Marketing, Vol 13, No. 1 (1998): pg. 40-53. DOI. This article is (C) Emerald and permission has been granted for this version to appear in e-Publications@Marquette. Emerald does not grant permission for this article to be further copied/distributed or hosted elsewhere without the express permission from Emerald. 
NOT THE PUBLISHED VERSION; this is the author's final, peer-reviewed manuscript. The published version may be accessed by following the link in the citation at the bottom of the page.

Parasuraman, A., Berry, L.L. and Zeithaml, V.A. (1993), "Research note: more on improving service quality measurement," Journal of Retailing, Vol. 69, Spring, pp. 140-7.

Parasuraman, A., Zeithaml, V.A. and Berry, L.L. (1985), "A conceptional model of service quality and its implication for future research," Journal of Marketing, Vol. 49, Fall, pp. 41-50.

Parasuraman, A., Zeithaml, V.A. and Berry, L.L. (1994). "Reassessment of expectations as a comparison standard in measuring service quality: implications for further research," Journal of Marketing, Vol. 58, January, pp. 111-24.

Patterson, P.G. and Johnson, L. (1993), "Disconfirmation of expectations and the gap model of service quality: an integrated paradigm," Journal of Consumer Satisfaction, Dissatisfaction and Complaining Behavior, Vol. 6, pp. 90-9.

Quelch, J.A. and Ash, S.B. (1981), "Consumer satisfaction with professional services," in Donnelly, J.H. and George, W.R. (Eds), Marketing of Services, American Marketing Association, Chicago, IL, pp. 82-5.

Rayunathan, P.S., Bagchi, P.K. and Bardi, E.J. (1988), "Motor carrier services: the US experience," International Journal of Physical Distribution Management, Vol. 18 No. 5, pp. 3-7.

Schary, P.B. (1979). "Management control over customer service," International Journal of Physical Distribution \& Materials Management, Vol. 10 No. 4, pp. 147-59.

Weitzel, W., Schwarzkopf, A.B. and Peach, E.B. (1989), "The influence of employee perceptions of customer service on retail store sales," Journal of Retailing, Vol. 65, Spring, pp. 27-39.

Westbrook, R.A. (1981), "Sources of consumer satisfaction with retail outlets," Journal of Retailing, Vol. 57, Fall, pp. 68-85.

Zeithaml, V.A., Parasuraman, A. and Berry, L.L. (1990), Delivering Quality Service, Free Press, New York, NY.

This summary has been provided to allow managers and executives a rapid appreciation of the content of this article. Those with a particular interest in the topic covered may then read the article in toto to take advantage of the more comprehensive description of the research undertaken and its results to get the full benefit of the material present

Journal of Business and Industrial Marketing, Vol 13, No. 1 (1998): pg. 40-53. DOI. This article is (C Emerald and permission has been granted for this version to appear in e-Publications@Marquette. Emerald does not grant permission for this article to be further copied/distributed or hosted elsewhere without the express permission from Emerald. 
NOT THE PUBLISHED VERSION; this is the author's final, peer-reviewed manuscript. The published version may be accessed by following the link in the citation at the bottom of the page.

\section{Executive summary and implications for managers and executives}

\section{Service quality and relationship marketing: it's not as easy as it looks}

Service quality matters as much in business-to-business services as it does for consumer services. Yet, as Mehta and Durvasula report, studies of service quality in business-to-business services are few and limited. In understanding service quality we focus on the interaction between customer and service provider. This service encounter is pretty simple in most consumer situations whereas business-to-business service encounters are often long drawn out and complicated.

At the heart of this complexity lies the fact that relationships between the service company and the customer company involve many people. The shipping services studied by Mehta and Durvasula break down the process into separate departments - sales, bookings, documentation, operations and claims - each having a direct relationship with the customer. We can see the same complex set of relationships in other services.

As well as the departmentalized nature of the service provider, we often see a similar pattern for the customer. Production, distribution, accounting, sales and planning departments may all have direct links with the shipping company. And the more people involved the greater chance there is of service breakdown or relationship problems. Thus, service quality in business-to- business industry has the additional dimension of the corporate interaction applying to the customer not just the supplier.

Mehta and Durvasula use the established SERVQUAL instrument for their assessment of service quality issues in the shipping industry. It's worth reminding ourselves (as the authors make plain) that SERVQUAL, for all its value, has a number of critics. These criticisms are of three types:

- SERVQUAL dimensions are insufficiently independent;

- SERVQUAL focuses on expectation-perception gaps rather than performance;

- SERVQUAL standardizes the analysis of services.

Each criticism has value in that they allow the manager using SERVQUAL to act with caution (even scepticism) when dealing with the outcome of research. SERVQUAL in no way represents an unchallengeable means of identifying service problems and managers need to be aware of this position.

Journal of Business and Industrial Marketing, Vol 13, No. 1 (1998): pg. 40-53. DOI. This article is (C) Emerald and permission has been granted for this version to appear in e-Publications@Marquette. Emerald does not grant permission for this article to be further copied/distributed or hosted elsewhere without the express permission from Emerald. 
NOT THE PUBLISHED VERSION; this is the author's final, peer-reviewed manuscript. The published version may be accessed by following the link in the citation at the bottom of the page.

I do not propose to discuss the specific example of ocean freight studied by Mehta and Durvasula. Instead I will look at how their findings might be applied to business-to-business services in general.

Two approaches suggest themselves to me. Either to give one individual responsibility for the entire relationship between the service business and the customer or else to put greater stress on service quality issues at all points of contact between service provider and customer. These two approaches are not mutually exclusive but they do require different management skills in their application.

\section{Account management}

Mehta and Durvasala suggest account management as one possible approach to handling service quality issues. Indeed, the translation of sales staff into account managers receives considerable attention especially wherefirms employ relationship marketing strategies. Problems arise in securing the attitudinal and cultural changes in salespeople and sales managers. When your remuneration depends on sales volume a change to "relationship value" challenges the ethos of selling. We cannot assume that the "top" sales person will necessarily become the best relationship manager.

Although this problem exists, sales people remain the best source of account managers. Existing relationships, a customer-oriented outlook, adaptability and personal communications skills all take on a great significance in relationship marketing. However, it's difficult to ignore the reaction of other staff who enjoy links with customers. Not only do such people value customer contact but also they can take against salespeople muscling in and telling them how to do their job!

Managing a change to relationship management requires changes to firm power structures and we can expect these changes will meet with resistance. Setting the relationship marketing strategy is one thing. Creating strategies that support such a policy - training, human resources, distribution and so on - can prove by far the greater challenge.

\section{Creating a service quality culture}

The alternative to giving account managers the power of life and death in service relationships is to devolve the responsibility for quality to all those dealing with customers. Again this simple concept is constrained by practical considerations:

- the blame culture - who's responsible for the service breakdown?

- conflict between cost control and service quality - unlike quality of goods there is little cost gain in service quality improvements;

Journal of Business and Industrial Marketing, Vol 13, No. 1 (1998): pg. 40-53. DOI. This article is @ Emerald and permission has been granted for this version to appear in e-Publications@Marquette. Emerald does not grant permission for this article to be further copied/distributed or hosted elsewhere without the express permission from Emerald. 
NOT THE PUBLISHED VERSION; this is the author's final, peer-reviewed manuscript. The published version may be accessed by following the link in the citation at the bottom of the page.

- customer confusion - where does the customer with a problem go?

Each of these considerations needs squaring in a relationship marketing strategy founded on service quality. Individuals interacting with customers need a focus on service quality - no one denies that - but such a concept needs a central champion. We are back to the problem of account management!

Mehta and Durvasula show how the measurement of service quality in business-to-business environments can use ideas created for consumer services. And, by doing so, the authors give managers in business-tobusiness services a new avenue to look for ways to improve service quality. Linking this with the acknowledged advantages enjoyed by business-tobusiness firms in developing relationships must help to improve service delivery.

However, much remains to be dome in understanding the nature and dynamics of service relationships. SERVQUAL helps the manager rather more than the researcher by allowing a focus on service process issues. And services managers must acknowledge the need to change culture alongside organizational developments. If this does not take place then we face the prospect of relationship marketing getting the reputation for being a cute theory but not much use in practice.

(A précis of the article "Relationships between SERVQUAL dimensions and organizational performance in the case of a business-to-business service." Supplied by Marketing Consultants for MCB University Press.)

Journal of Business and Industrial Marketing, Vol 13, No. 1 (1998): pg. 40-53. DOI. This article is (C) Emerald and permission has been granted for this version to appear in e-Publications@Marquette. Emerald does not grant permission for this article to be further copied/distributed or hosted elsewhere without the express permission from Emerald. 
NOT THE PUBLISHED VERSION; this is the author's final, peer-reviewed manuscript. The published version may be accessed by following the link in the citation at the bottom of the page.

Table I. Performance evaluation of interfacing departments/activities: strong points and weak points

Department/activity Strong points

Booking service
mean $=5.68$
items $=8$
alpha $=0.95$
Operations
mean $=5.58$
items $=7$
alpha $=0.92$
Documentation
mean $=5.55$
items $=6$
alpha $=0.94$
Telephone services
mean $=5.46$
items $=5$
alpha $=0.92$
items $=8$
alpha $=0.91$
Marketing reps
mean $=5.38$
(5.75)
Availability of space (6.09)

Ease of contact (5.92)

Handling of sailing inq (5.84)

Handling of rate/enq. (5.76)

Container type available (5.81)

Prompt release of empty containers (5.77)

Condition of container. (5.64)

Speedy release of delivery order (5.79)

Speedy release of bill of lading

Give needed info (5.52)

Prompt follow-up of inquiries (5.49)

Directing to right person (5.47)

Courtesy/etiquette $(5.46)$

Fulfil promises (5.71)

Personalized services (5.66)

Client relationship (5.63)

Help in unforeseen

situation (5.56)

Product/route knowledge (5.52)

Personal visits to

shipping line office

mean $=5.31$

Location (5.56)

Courtesy/etiquette (5.40)

items $=9$

alpha $=0.95$

Give needed info (5.36)

Prompt attention (5.36)

Directing to right person (5.35)

Claims
mean $=4.94$
items $=3$
alpha $=0.95$

Notes:

Figures in parentheses are item means
Weak points

Advice on delays (5.21)

Telephone courtesy/politeness (5.50)

Accuracy/reliability of info (5.54)

Handling closing time inquiries (5.57)

Ability to get assistance for port (5.39)

Assistance on closing extension (5.39)

Handling of LCL cargo (5.52)

Availability of space at godown (5.56)

Flexibility in releasing bill of lading (5.37)

Accommodation special needs (5.40)

Accuracy and neatness (5.49)

Flexibility in releasing deliv order (5.53)

Promptness in answering (5.36)

Regularity of visits (4.54)

Get co-operation from others in company (5.14)

Personal attributes (5.30)

Sensitive to customers (5.02)

Waiting period (5.05)

Professional appraisal (5.26)

Atmosphere/environment (5.33)

Speedy action (4.83)

Claims procedures (4.89)

Journal of Business and Industrial Marketing, Vol 13, No. 1 (1998): pg. 40-53. DOI. This article is @ Emerald and permission has been granted for this version to appear in e-Publications@Marquette. Emerald does not grant permission for this article to be further copied/distributed or hosted elsewhere without the express permission from Emerald. 
NOT THE PUBLISHED VERSION; this is the author's final, peer-reviewed manuscript. The published version may be accessed by following the link in the citation at the bottom of the page.

LCL denotes less than containers load

Alpha represent Cronbach alpha, a measure of scale reliability

Table II. SERVQUAL: expectations and perceptions scores

\begin{tabular}{|c|c|c|}
\hline SERVQUAL factor & Strong points & Weak points \\
\hline $\begin{array}{l}\text { Assurance } \\
\text { mean }(\mathrm{P}=5.61, \mathrm{E}=5.94) \\
\text { items }=4 \\
\alpha(\mathrm{E})=0.81 \alpha(\mathrm{P})=0.84 \\
\text { imp. score }=17.69 \% \\
\text { gap }=0.33\end{array}$ & $\begin{array}{l}\text { Customers feel safe in } \\
\text { their transactions } \\
\quad(\mathrm{P}=5.84, \mathrm{E}=5.93) \\
\text { Employees instil confidence } \\
\quad(\mathrm{P}=5.62, \mathrm{E}=5.98)\end{array}$ & $\begin{array}{l}\text { Employees are consistently } \\
\text { courteous }(\mathrm{P}=5.48, \mathrm{E}=5.84) \\
\text { Employees knowledgeable to } \\
\text { answer questions } \\
(\mathrm{P}=5.51, \mathrm{E}=6.00\end{array}$ \\
\hline $\begin{array}{l}\text { Responsiveness } \\
\text { mean }(\mathrm{P}=5.54, \mathrm{E}=6.03) \\
\text { items }=4 \\
\alpha(\mathrm{E})=0.87 \alpha(\mathrm{P})=0.90 \\
\text { imp. score }=21.02 \% \\
\text { gap }=0.49\end{array}$ & $\begin{array}{l}\text { Employees always willing } \\
\text { to help } \\
(\mathrm{P}=5.71, \mathrm{E}=6.24) \\
\text { Employees give prompt } \\
\text { services }(\mathrm{P}=5.58, \mathrm{E}=6.14) \\
\text { Employees tell when exactly } \\
\text { service will be performed } \\
(\mathrm{P}=5.54, \mathrm{E}=5.92)\end{array}$ & $\begin{array}{l}\text { Never too busy to respond } \\
\quad \text { requests }(\mathrm{P}=5.33, \mathrm{E}=5.81)\end{array}$ \\
\hline $\begin{array}{l}\text { Reliability } \\
\text { mean }(\mathrm{P}=5.46, \mathrm{E}=6.01) \\
\text { items }=5 \\
\alpha(\mathrm{E})=0.81 \alpha(\mathrm{P})=0.89 \\
\text { imp. score }=30.0 \% \\
\text { gap }=0.55\end{array}$ & $\begin{array}{l}\text { Sincere interest in solving } \\
\text { problems } \\
(\mathrm{P}=5.85, \mathrm{E}=6.33) \\
\text { Services provided at promised } \\
\text { time }(\mathrm{P}=5.55, \mathrm{E}=6.05) \\
\text { When promises to do } \\
\text { something by certain time, } \\
\text { it does so } \\
(\mathrm{P}=5.51, \mathrm{E}=6.17)\end{array}$ & $\begin{array}{l}\text { Error free records } \\
\quad(P=5.03, E=5.60) \\
\text { Service performed right the } \\
\text { first time }(P=5.46, E=5.88)\end{array}$ \\
\hline $\begin{array}{l}\text { Empathy } \\
\text { mean }(\mathrm{P}=5.38, \mathrm{E}=5.76) \\
\text { items }=5 \\
\alpha(\mathrm{E})=0.83 \alpha(\mathrm{P})=0.86 \\
\text { imp. score }=14.56 \% \\
\text { gap }=0.38\end{array}$ & $\begin{array}{l}\text { Customers best interest at } \\
\text { heart }(\mathrm{P}=5.71, \mathrm{E}=6.06) \\
\text { Understand specific customer } \\
\text { needs }(\mathrm{P}=5.64, \mathrm{E}=5.97) \\
\text { Give personal attention } \\
(\mathrm{P}=5.53, \mathrm{E}=5.66)\end{array}$ & $\begin{array}{l}\text { Convenient operating hours } \\
(\mathrm{P}=5.00, \mathrm{E}=5.40) \\
\text { Give individual attention } \\
(\mathrm{P}=5.27, \mathrm{E}=5.70)\end{array}$ \\
\hline $\begin{array}{l}\text { Tangibles } \\
\text { mean }(\mathrm{P}=5.04, \mathrm{E}=4.92) \\
\text { items }=4 \\
\alpha(\mathrm{E})=0.58 \alpha(\mathrm{P})=0.72 \\
\text { imp. score }=16.99 \% \\
\text { gap }=0.08\end{array}$ & $\begin{array}{l}\text { Modern looking equipment } \\
(P=5.17, E=5.00) \\
\text { Neat-appearing employees } \\
(P=5.09, E=4.69)\end{array}$ & $\begin{array}{l}\text { Visually appealing promotional } \\
\text { material }(\mathrm{P}=4.93, \mathrm{E}=4.92) \\
\text { Visual appealing physical } \\
\text { facilities }(\mathrm{P}=4.89, \mathrm{E}=4.99)\end{array}$ \\
\hline
\end{tabular}

Journal of Business and Industrial Marketing, Vol 13, No. 1 (1998): pg. 40-53. DOI. This article is @ Emerald and permission has been granted for this version to appear in e-Publications@Marquette. Emerald does not grant permission for this article to be further copied/distributed or hosted elsewhere without the express permission from Emerald. 
NOT THE PUBLISHED VERSION; this is the author's final, peer-reviewed manuscript. The published version may be accessed by following the link in the citation at the bottom of the page.

Notes:

$\mathrm{P}$ denotes perceptions and $\mathrm{E}$ denotes expectations

Dimensions are in descending order of perception scores

Mean dimension score is used as cut off to divide items into strong and weak points

a (P) and a (E) are Cronbach alpha values for perception and expectation scores

Table III. Correlations between SERVQUAL and overall line evaluation using different models

\begin{tabular}{lcccc}
\hline & \multicolumn{4}{c}{ Overall line evaluation } \\
SERVQUAL factor & $\begin{array}{c}\text { Performance } \\
\text { (unweighted) }\end{array}$ & $\begin{array}{c}\text { Performance } \\
\text { (weighted) }\end{array}$ & $\begin{array}{c}\text { Gaps } \\
\text { (unweighted) }\end{array}$ & $\begin{array}{c}\text { Gaps } \\
\text { (weighted) }\end{array}$ \\
\hline Assurance & 0.51 & $0.03^{*}$ & 0.21 & $0.07^{*}$ \\
Responsiveness & 0.54 & $0.14^{*}$ & 0.23 & 0.18 \\
Reliability & 0.50 & $0.09^{*}$ & 0.23 & 0.29 \\
Empathy & 0.45 & 0.31 & 0.29 & 0.20 \\
Tangibles & 0.29 & $0.09^{*}$ & $0.11^{*}$ & 0.22
\end{tabular}

Note: All correlations are significant at alpha $=0.05$ unless marked as $*$ 
NOT THE PUBLISHED VERSION; this is the author's final, peer-reviewed manuscript. The published version may be accessed by following the link in the citation at the bottom of the page.

Table IV. Correlations between SERVQUAL dimensions using perceptions scores and interfacing departments/activities

\begin{tabular}{|c|c|c|c|c|c|c|c|}
\hline $\begin{array}{l}\text { Department/ } \\
\text { activity }\end{array}$ & Assurance & Responsive & $\begin{array}{r}\text { Dimensi } \\
\text { Reliability }\end{array}$ & $\begin{array}{l}\text { ons } \\
\text { Empathy }\end{array}$ & Tangibles & Total & Evaluation \\
\hline $\begin{array}{c}\text { Booking } \\
\text { services }\end{array}$ & 0.54 & 0.54 & 0.56 & 0.49 & 0.37 & 0.57 & 0.63 \\
\hline Operations & 0.62 & 0.59 & 0.60 & 0.47 & 0.45 & 0.61 & 0.67 \\
\hline Documentation & 0.47 & 0.52 & 0.52 & 0.45 & 0.36 & 0.52 & 0.69 \\
\hline $\begin{array}{l}\text { Telephone } \\
\text { service }\end{array}$ & 0.50 & 0.54 & 0.54 & 0.46 & 0.43 & 0.55 & 0.64 \\
\hline $\begin{array}{l}\text { Sales/ } \\
\text { marketing reps }\end{array}$ & 0.52 & 0.59 & 0.60 & 0.52 & 0.35 & 0.58 & 0.68 \\
\hline Personal visits & 0.62 & 0.60 & 0.61 & 0.54 & 0.43 & 0.64 & 0.63 \\
\hline Claims & 0.45 & 0.49 & 0.54 & 0.43 & 0.48 & 0.53 & 0.37 \\
\hline Mean correlations & 0.53 & 0.55 & 0.57 & 0.48 & 0.41 & 0.57 & 0.62 \\
\hline
\end{tabular}

Note: All correlations are significant at alpha $=0.05$ 